\title{
СОРТОВА МІНЛИВІСТЬ МАТОЧНИХ КОРЕНЕПЛОДІВ БУРЯКА СТОЛОВОГО СОРТУ БОРДО ХАРКІВСЬКИЙ
}

\author{
С. І. Корнієнко \\ Інститут овочівництва і баштанництва НААН
}

Визначено реакцію сорту буряка столового Бордо харківський на метеорологічні умови 2000-2011 рр., виявлено роки-еталони за сумою опадів і температури, відносною вологістю повітря, за допомогою коефіцієнта еластичності (Е) визначено вплив метеорологічних умов на показники урожайності маточних коренеплодів за роками досліджень. Встановлено, що формування якісної товарної продукції маточних коренеплодів буряка столового знаходиться у прямій залежності від суми опадів $(\mathrm{r}=0,69)$, суми температур $(\mathrm{r}=0,51)$ і відносної вологості повітря. Виявлено, що із збільшенням відносної вологості повітря на 1 \% урожайність маточних коренеплодів буряка столового підвищується на 580 кг, за умов підвищення суми ефективних температур на $1{ }^{\circ} \mathrm{C}$ урожайність зменшується на 17 кг, від збільшення суми опадів на 1мм підвищення урожайності маточних коренеплодів становить 54 кг.

Буряк столовий, маточний коренеплід, врожайність, коефіцієнт еластичності.

Вступ. Встановлення реакції сорту на метеорологічні умови $є$ важливим крітерієм прогнозування урожайності та збереження сортової чистоти. В останні роки у зв'язку з різкою зміною погодних умов місцеві адаптивні сорти втрачають свої кількісні ознаки, знижуються індекси форми коренеплодів, що призводить до мінливості апробаційних ознак. Отже для нас важливим науковим завданням було встановлення реакції сорту буряка столового Бордо харківський на погодні умови за кількісною ознакою урожайності.

Методика досліджень. Аналіз проводили за дослідженнями 2000-2011 років на стаціонарному технолого-агрохімічному фоні (Романов О. В., Куц О. В., Томах Є. О.) при механізованій сівбі насіння у III декаді квітня - I декаді травня, за норми висіву - 12 кг/га, шириною міжрядь - 70 см, глибиною загортання - 2 см, попередник - ячмінь. Восени лущіння стерні проводилося тракторами МТЗ-80 + БДТ-3, зяблева оранка - Т-150 + ПЛН-5-3,5 та культивація МТЗ-80 + КПС-4 + БЗСС-1,0. Навесні проводилося боронування - Т-70 + СЛ + БЗСС-10. За вегетацію проводили два міжрядних механізованих розпушування

(C) С. І. Корнієнко. 2012.

ISSN 0582-5075. Селекція і насінництво. 2012. Випуск 102. 
3 ручним прополюванням у рядках. Площа облікової ділянки 20 м $^{2}[1,2]$. Визначення впливу погодних умов на показники урожайності проводилося на контрольних ділянках дослідів з вирощування коренеплодів буряка столового Бордо харківський (без додаткового штучного зрошення).

Для встановлення дії погодних умов суми опадів (мм) і температур ${ }^{0} \mathrm{C}$ та відносної вологості повітря використовували методику Л. В. Сазонової [3]. Коефіцієнт еластичності (Е) розраховували за формулою Г. Л. Громико [4]:

$$
E=a_{1} \frac{x}{a_{0}+a_{1} x} ;
$$

Коефіцієнти регресії розраховували згідно методичних рекомендацій [5]:

$$
\begin{gathered}
a_{1}=\frac{\sum x y-x y \cdot n}{\sum x^{2}-(x)^{2} \cdot n}, \\
\mathrm{a}_{0}=\mathrm{y}-\mathrm{a}_{1} \mathrm{x}, \\
\mathrm{y}_{\mathrm{x}}=\mathrm{a}_{\mathrm{o}}+\mathrm{a}_{1} \mathrm{x} .
\end{gathered}
$$

Результати досліджень. Встановлено, що урожайність маточних елітних коренеплодів буряка столового за роки досліджень коливалась від 24,7 до 55,0 т/га, сума опадів міn 225 - $\max 500$ мм, сумарна кількість температури від 2883 до $3824{ }^{0} \mathrm{C}$ (рис. 1, 2); відносна вологість повітря 64-75\%.

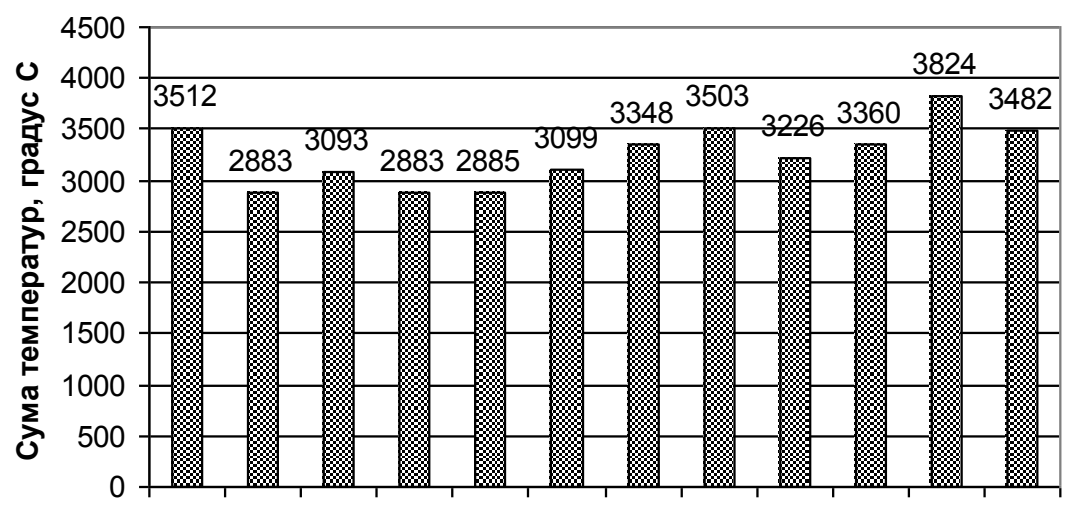

200020012002200320042005200620072008200920102011

Роки досліджень

Рис. 1. Мінливість суми температур залежно від умов року (2000-2011 pp.)

За результатами досліджень встановлено, що еталонними роками, які забезпечують збільшення урожайності до 49,6; 54,5; 55,0 і 50,7 т/га є 2000, 2001, 2002 та 2004, сума опадів у них складала 398 мм, 256 мм, 360 мм, 500 мм та температур $3512^{\circ} \mathrm{C}, 2883^{\circ} \mathrm{C}, 3099^{\circ} \mathrm{C}, 2085^{\circ} \mathrm{C}$. 


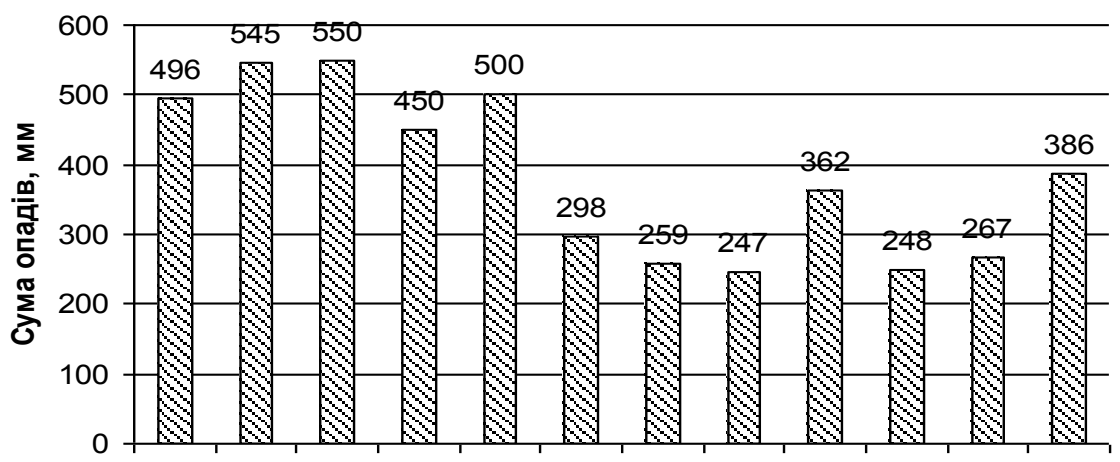

200020012002200320042005200620072008200920102011

Роки досліджень

Рис. 2. Мінливість суми опадів залежно від умов року, мм, 2000-2011 рр.

Доведено, що сума опадів значно вплинула на урожайність маточних коренеплодів, але чіткої залежності не визначено, так у 2004 році за сумарної кількості за рік 500 мм урожайність була 50,7 т/га, тоді як у 2001 році за 256 мм вона була 54,5 т/га (табл. 1).

Таблиця 1

Залежність урожайності буряка столового сорту Бордо харківський від суми опадів (за Г. Л. Громико, 1981).

\begin{tabular}{|c|c|c|c|c|c|c|}
\hline Рік & $\begin{array}{c}\text { Сума } \\
\text { опадів, } \\
\text { X }\end{array}$ & $\begin{array}{c}\text { Урожай- } \\
\text { жай- } \\
\text { ність, } \\
\text { т/га, У }\end{array}$ & $X^{2}$ & $\mathrm{y}^{2}$ & XУ & $\begin{array}{l}\text { Е (\% підвищен- } \\
\text { ня урожайності } \\
\text { при збільшенні } \\
\text { опадів на } 1 \%)\end{array}$ \\
\hline 2000 & 398 & 49,6 & 158404 & 2460,16 & 19740,8 & 0,51 \\
\hline 2001 & 256 & 54,5 & 65536 & 2970,25 & 13952,0 & 0,40 \\
\hline 2002 & 360 & 55,0 & 129600 & 3025,00 & 19800,0 & 0,49 \\
\hline 2003 & 450 & 33,3 & 202500 & 1108,89 & 14985,0 & 0,54 \\
\hline 2004 & 500 & 50,7 & 250000 & \begin{tabular}{|l|}
2570,49 \\
\end{tabular} & 25350,0 & 0,57 \\
\hline 2005 & 300 & 29,8 & 90000 & 888,04 & 8940,0 & 0,44 \\
\hline 2006 & 200 & 25,9 & 40000 & 670,81 & 5180,0 & 0,35 \\
\hline 2007 & 210 & 24,7 & 44100 & 610,09 & 5187,0 & 0,36 \\
\hline 2008 & 345 & 36,2 & 119025 & 1310,44 & 12489,0 & 0,48 \\
\hline 2009 & 233 & 27,8 & 54289 & 772,84 & 6477,4 & 0,38 \\
\hline 2010 & 356 & 26,7 & 126736 & 712,89 & 9478,5 & 0,48 \\
\hline 2011 & 225 & 38,6 & 50625 & 1489,96 & 8685,0 & 0,37 \\
\hline & $\Sigma X 3833$ & $\Sigma 452,8$ & 133081 & \begin{tabular}{|l|}
18589,86 \\
\end{tabular} & 150264,7 & \\
\hline & x 319 & y 37,7 & & 15491,55 & & \\
\hline
\end{tabular}


Визначено, що кореляція між урожайністю маточних коренеплодів та сумою опадів складає 0,69 . Підвищення урожайності маточних коренеплодів від збільшення суми опадів на 1мм становить 54 кг.

За коефіцієнтом еластичності (Е) визначено, на скільки відсотків результативна ознака урожайності $(\mathrm{У})$ маточних коренеплодів підвищиться зі збільшенням суми опадів $(\mathrm{X})$ на $1 \%$. Найбільший коефіцієнт підвищення урожайності 0,$51 ; 0,49 ; 0,54 ; 0,57$ спостерігали відповідно у 2000, 2002, 2003 і 2004 роках. Отже, висока урожайність коренеплодів буряка столового більшою мірою відмічається при високій кількості суми опадів.

При статистичному аналізі врожайності буряка столового визначено значне варіювання цього показника. Відмічено залежність не тільки від опадів, а більшою мірою від суми температур (табл. 2).

Таблиця 2

Залежність урожайності маточних коренеплодів буряка столового від суми температур за вегетаційний період та відносної вологості повітря.

\begin{tabular}{|c|c|c|c|c|c|}
\hline \multirow[t]{2}{*}{ Рік } & \multirow{2}{*}{$\begin{array}{c}\text { Сума } \\
\text { температур, } \\
{ }^{0} \mathrm{C}\end{array}$} & \multirow{2}{*}{$\begin{array}{c}\text { Відносна } \\
\text { вологість } \\
\text { повітря, } \\
\%\end{array}$} & \multirow{2}{*}{$\begin{array}{c}\text { Урожайність, } \\
\text { т/га }\end{array}$} & \multicolumn{2}{|c|}{$\begin{array}{c}\text { Коефіцієнт } \\
\text { еластичності Е (\% під- } \\
\text { вищення урожайності } \\
\text { при зміні на } 1 \text { \%:) }\end{array}$} \\
\hline & & & & $\begin{array}{c}\text { суми } \\
\text { темпера- } \\
\text { тур }\end{array}$ & $\begin{array}{c}\text { відносної } \\
\text { вологості } \\
\text { повітря }\end{array}$ \\
\hline 2000 & 3512 & 72 & 49,6 & $-1,78$ & 1,09 \\
\hline 2001 & 2883 & 71 & 54,5 & $-1,11$ & 1,18 \\
\hline 2002 & 3093 & 64 & 55,0 & $-1,30$ & 1,10 \\
\hline 2003 & 2883 & 67 & 33,3 & $-1,11$ & 1,09 \\
\hline 2004 & 2885 & 73 & 50,7 & $-1,11$ & 1,10 \\
\hline 2005 & 3099 & 68 & 29,8 & $-1,30$ & 1,09 \\
\hline 2006 & 3348 & 68 & 25,9 & $-1,57$ & 1.10 \\
\hline 2007 & 3503 & 71 & 24,7 & $-1,77$ & 1,10 \\
\hline 2008 & 3226 & 72 & 36,2 & $-1,43$ & 1,09 \\
\hline 2009 & 3360 & 75 & 27,8 & $-1,59$ & 1,09 \\
\hline 2010 & 3824 & 75 & 26,7 & $-2,31$ & 1,09 \\
\hline 2011 & 3482 & 73 & 38,6 & $-1,75$ & 1,09 \\
\hline
\end{tabular}

При аналізі регресивної залежності зміни урожайності маточних коренеплодів від суми ефективних температур було встановлено ії зменшення на 17 кг за умов підвищення суми ефективних температур на $1{ }^{\circ} \mathrm{C}$.

За коефіцієнтом еластичності (Е) найбільше зниження урожайності було в роки з більш високими сумами температур. Так, в 2007 році таке зниження становило $1,77 \%$ від зміни суми температур на $1 \%$, у 2010 р. за суми температур $3824{ }^{0} \mathrm{C}-2,31 \%$. Залежність між урожайністю маточних коренеплодів та сумою температури складає за коефіцієнтом кореляції $\mathrm{r}=0,51$. 
За аналізом залежності урожайності маточних коренеплодів буряка столового сорту Бордо харківський від відносної вологості повітря за коефіцієнтом регресії виявлено, що зі статистичним збільшенням першого показника на 1 \% урожайність маточних коренеплодів буряка столового підвищилась на 580 кг. Тобто, з розглянутих факторів відносна вологість повітря має великий вплив на урожайність.

Коефіцієнт еластичності також вказує на пряму пропорційну залежність врожайності маточних коренеплодів від підвищення відносної вологості повітря на $1 \%$ (у даному випадку на $1,09 \%$ ).

Висновки. Формування якісної товарної продукції маточних коренеплодів буряка столового знаходиться у прямій залежності від суми опадів $(\mathrm{r}=0,69)$, суми температур $(\mathrm{r}=0,51)$ і відносної вологості повітря. Підвищення урожайності маточних коренеплодів від збільшення суми опадів на 1 мм становить 54 кг. За регресивною залежністю виявлено, що зі статистичним збільшенням відносної вологості повітря на $1 \%$ урожайність маточних коренеплодів буряка столового підвищується на 580 кг. При аналізі регресивної залежності зміни урожайності маточних коренеплодів від суми ефективних температур встановлено ії зменшення на 17 кг за умов підвищення суми ефективних температур на $1{ }^{0} \mathrm{C}$.

\section{Список використаних джерел}

1. Сучасні методи селекції овочевих і баштанних культур / [за ред. Т. К. Горової, К. І. Яковенко]: - Х., 2001. - С. 432-456.

2. Методика дослідницької справи / [за ред. Г. Л. Бондаренко, К. І. Яковенко]: - Х.., Основа, 2001. - 369 с.

3. Сазонова Л. В. Корнеплодные овощные растения / Л. В. Сазонова, Э. А. Власова. - Л., ВО Агропромиздат, 1990. - 295 с.

4. Косая Г. Л. Статистика / Г. Л. Косая, Г. Л. Громико. - М.: Московський університет, 1981. $-408 \mathrm{c.}$

5. Лакин Г. Ф. Биометрия / Г. Ф. Лакин. - М.: Высшая школа, 1990. -352с.

Определена реакция сорта свеклы столового Бордо харьковский на метеорологические условия 2000-2011 гг., выявлены годы эталоны по сумме осадков и температуры, относительной влажностью воздуха, посредством коэффициента эластичности (Е) определено влияние метеорологических условий на показатели урожайности маточных корнеплодов за годами исследований. Установлено, что формирование качественной товарной продукции маточных корнеплодов свеклы столового находится в прямой зависимости от суммы осадков $(\mathrm{r}=0,69)$, суммы температур $(\mathrm{r}=0,51)$ и относительной влажности воздуха. Выявлено, что с увеличением относительной влажности воздуха на $1 \%$ урожайность маточных корнеплодов свеклы столового повышается на 580 кг, при условиях повышения суммы эффективных температур на $1{ }^{0} \mathrm{C}$ урожайность уменьшается на 17 кг, от увеличения суммы осадков на 1мм повышение урожайности маточных корнеплодов составляет 54 кг. 
The reaction of the varieties of beet Bordo Kharkov on meteorological conditions in the years 2000-2011 is defined, the standards for the sample years in precipitation and temperature, relative humidity, by using the coefficient of elasticity (E) are established, the effect of meteorological conditions on crop yields uterine roots for years of researches are determined. It is established that the formation of high-quality commercial products of uterine beet root is in direct proportion to the amount of precipitation $(r=0,69)$, the amount of te mperature $(\mathrm{r}=0,51)$ and relative humidity. It was found that with increasing relative humidity of $1 \%$ the yield of uterine beet root is increased by $580 \mathrm{~kg}$, under conditions of increasing the amount of effective temperatures for $1{ }^{\circ} \mathrm{C}$ yields are reduced by $17 \mathrm{~kg}$, the increase in total rainfall of $1 \mathrm{~mm}$ enlarges the yields of uterine roots to $54 \mathrm{~kg}$. 